\title{
Attitudes and beliefs about environmental hazards in three diverse communities in Texas on the border with Mexico
}

\author{
Theresa L. Byrd, ${ }^{1}$ James VanDerslice, ${ }^{2}$ and Susan K. Peterson ${ }^{3}$
}

ABSTRACT Objective. Since communicating risk related to environmental hazards has consistently presented a challenge to government agencies and industries, our objective was to better understand the attitudes and beliefs of three communities, so as to help agencies and industries develop better risk communication interventions.

Methods. We explored attitudes and beliefs about environmental risks in three diverse communities in Texas on the border with Mexico, in the county of El Paso. During the summer of 1995, using a door-to-door survey, we interviewed 147 individuals, using a questionnaire based upon an existing instrument. Interviews were conducted in three very different areas of the county: semirural low-income, urban low-income, and suburban upper-income. We randomly selected specific sections in each of the three communities for inclusion in the sample. We assessed attitudes and beliefs about regulations and experts, risk and hazards, and how to address environmental issues.

Results. Attitudes and beliefs varied among the three communities, especially in the assessment of riskiness of various hazards. In general, there was mistrust of government agencies and of industries, a strong feeling that the environment can be improved, and a lack of understanding about what actions individuals might take to improve the environment.

Discussion. Agencies need to find ways to increase their credibility with the public, and they should assess communities in order to understand the attitudes of the residents.

Key words Surveys, environmental health, public opinion, Texas, Hispanic Americans.

Government agencies and industries often are responsible for communicating environmental risk information to

1 University of Texas-Houston, School of Public Health at El Paso, El Paso, Texas, United States of America. Send correspondence to: Theresa L. Byrd, University of Texas, School of Public Health, 1100 North Stanton, Suite 110, El Paso, TX 79902, United States of America; telephone: (915) 747-8504; fax: (915) 747-8512; e-mail: Tbyrd@utep.edu

2 State of Washington, Department of Health, Office of Environmental Health Assessments Services, Olympia, Washington, United States of America.

3 University of Texas, M. D. Anderson Cancer Center, Department of Behavioral Science, Houston, Texas, United States of America. the public regarding, for example, regulatory decisions, industrial practices, or adverse events. Communicating risk related to environmental hazards has consistently presented a challenge to government agencies and industries. Recommendations regarding how agencies and industries should conduct effective risk communication have been developed and published (1-4). Despite these efforts, agencies and industries continue to encounter difficulties in effectively communicating with the public concerning environmental risks.
Risk communication problems stem not only from the message itself, but also from characteristics of the communicator and the audience, as well as the context in which the risk communication occurs (5). When evaluating environmental risks, government agencies and industries tend to view dimensions of the risk differently than the public (6). The public may tend to focus on more qualitative aspects of the risk (e.g., catastrophic potential, equity, dread, uncertainty) while agencies and industries tend to focus on aspects emphasized in the quantitative 
risk assessment process such as morbidity and mortality estimates (7).

Risk communicators have erroneously assumed that the public is a homogeneous group with regard to environmental risk perceptions (5). Different segments of the population frequently have disparate beliefs, attitudes, values, and levels of knowledge regarding environmental risk, as a result of underlying social, political, and economic differences (8). Failing to pay attention to the manner in which the public constructs its view of environmental risks and their attitudes and beliefs regarding those risks may negatively impact the risk communication process (5).

Even with a good understanding of a group's beliefs and attitudes, communication efforts can fail completely if the public lacks confidence in the entity providing information. Public confidence and trust in government and industry is often lacking, particularly when communities are facing contentious environmental issues (9-12). Many risk management and communication tensions and disputes have been attributed to the climate of mistrust between the public and others involved in risk management decisions, including government and industry $(11,12)$. Negative events, such as accidents or withholding information about risk events, can be memorable and may have a lasting detrimental impact on an agency's or industry's credibility (1). As with risk perception, various segments of the public may have different degrees of trust in government agencies or industries due to specific prior experiences or individual differences.

Government agency and industry representatives who are responsible for communicating with the public about environmental risks may not have an adequate understanding of the public's underlying attitudes and beliefs toward these risks, and how these beliefs can influence responses to their messages. Understanding the public's attitudes and beliefs toward environmental risks, along with the variations in those beliefs among different segments of the public, may help agency and industry professionals en- gage in more effective risk communication efforts. Such an understanding is particularly important for the border region of the United States of America and Mexico. This area is a unique blend of cultures, customs, and languages, and it encompasses a wide range of living conditions. In addition, tens of thousands of area residents move back and forth across the border on a daily basis, and many families have roots in both countries (13). Learning to effectively communicate information about environmental risks is especially important for agencies along the United States-Mexico border because of industrial growth due to the North American Free Trade Agreement (NAFTA), the community's growing awareness of health risks associated with environmental contamination, and the increasing concern about the movement of contaminants from each of the countries into the other. Over the last several years, local, state, and federal agencies from both of the countries have been working on a plan to address these issues (14). For environmental and health agencies to effectively disseminate information about environmental issues to community members, and to accurately gather information from these diverse communities regarding environmental problems and potential solutions, an understanding of the attitudes and beliefs of border residents around issues of environmental health is essential.

The purpose of this pilot study was to explore the attitudes and beliefs of three diverse communities in Texas on the United States-Mexico border regarding environmental hazards, government agencies, and the residents' ability to change the environment, as well as the implications that these findings have for future risk communication efforts.

\section{METHODS}

\section{Study communities}

According to the 1990 United States census, El Paso County, Texas, had a population of approximately 600000 residents. The vast majority of those persons were living in the city of $\mathrm{El}$ Paso, and over $70 \%$ of the county residents were Hispanic.

There is great variability in income and education levels within El Paso County. To assess the extent to which attitudes and beliefs varied within the area, we selected three very different communities, which will be referred to as Communities A, B, and C. All three of the communities are located in $\mathrm{El}$ Paso County, with two of them within the city limits.

Community A is located just outside the city limits of El Paso. It is a colonia, a low-income semirural area with much substandard housing and lacking such municipal services as piped water, sewerage, and garbage collection. According to the 1990 United States census, median per-capita income in this area was only US\$ 5 500, and almost $90 \%$ of the residents reported their ethnicity as Hispanic.

Communities B and C are both situated within the city of El Paso and receive all usual municipal services. Community B is a low-income neighborhood next to an industrial area containing chemical and garment manufacturing plants as well as two oil refineries. Over $95 \%$ of these residents are Hispanic, with a median per-capita income of only US\$ 4 600, according to the 1990 census. Community C is a higher-income suburban area of the city, consisting mostly of residences and retail businesses. The median percapita income of this area was almost US\$ 18 000, and only 40\% were Hispanic, according to the 1990 census.

\section{Instrument development}

Our study questionnaire was based on an existing instrument that Slovic and associates (15) developed for use in Canada, and we adapted it for our study. Our questionnaire included items regarding attitudes about regulations and experts, beliefs about the riskiness of various environmental contaminants, and attitudes and beliefs about how to address environmental problems. To assess these attitudes and 
beliefs, respondents were read a series of statements and asked to agree or disagree with each one, using a 4-point Likert scale ranging from "agree strongly" to "disagree strongly." To assess general perceptions of risk, respondents were given a list of hazards, and asked to rate the "riskiness" of each item, both for themselves and for the community as a whole, using a fivepoint Likert scale ranging from "very high risk" to "almost no risk." The results of the general perceptions of risk have been reported elsewhere (16).

\section{Data collection}

At the beginning of each day of data collection, a section of each of the three communities was randomly chosen. Interviewers approached each residence in this selected neighborhood; however, no attempts were made to return to homes where no one answered the door during the first attempt. The interviewers explained the purpose of the study, administered a written informed consent, and, if the resident agreed to participate, conducted the interview in the resident's home. Questionnaires were available in English or Spanish, and the participants were asked to choose the language that they felt most comfortable using. The interview was approximately 40 minutes long.

Interviewers included two of the authors, as well as four graduate students from the University of TexasHouston School of Public Health at El Paso. All interviewers were bilingual, and interviews were done in Spanish or English, depending upon the wishes of the respondent.

Data collection lasted from May to September 1995, during which 147 interviews were completed: 51 in Community A, 50 in Community B, and 46 in Community C. Of the residents who were contacted, fewer than $10 \%$ refused to participate.

\section{Data analysis}

We analyzed the survey data using SPSS for Windows Version 8.0 statisti- cal software (SPSS, Chicago, Illinois, United States of America). Frequencies and proportions were used to describe the sample. Comparisons of attitude responses were made across the three communities. The chi-square statistic was used to assess the statistical significance of these comparisons. Our tables accompanying this article indicate where there were statistically significant associations between the distribution of responses to the statement and the community of the respondents.

\section{RESULTS}

\section{Regulations and experts}

There were significant differences in attitudes among the three communities in the area of regulations and experts (Table 1). For example, among the residents of the higher-income, Community $\mathrm{C}$ neighborhood there was a general pattern of lower trust in experts, the government, and the efficacy of regulation. While around half of the respondents in the two lower-

TABLE 1. Attitudes and beliefs regarding environmental regulations and experts, El Paso County, Texas, 1995



\footnotetext{
${ }^{a}$ Community $\mathrm{A}$ is a low-income semirural area near the city of El Paso, Community B is a low-income neighborhood within the city of El Paso, and Community $\mathrm{C}$ is a higher-income suburban section of the city.

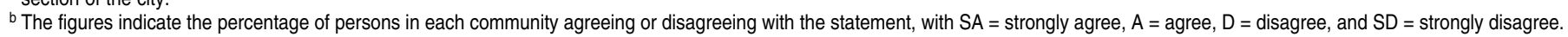

${ }^{\mathrm{c}}$ Statements for which there was a statistically significant association between the distribution of responses to the statement and the community of the respondents $(P \leq 0.03)$.
} 
income communities, A and B, strongly agreed with the statement that "experts are able to make true estimates of the health risks from chemicals in the environment," only $15 \%$ of the residents of Community $C$ held this view. Similarly, about a third of the sample from Communities A and B strongly agreed that decisions regarding risk should be left to these experts, but only $7 \%$ of the residents from the higher-income area strongly agreed with this statement.

Just under half of the overall sample agreed that there were enough laws to regulate chemical risks (Table 1). There appeared to be little confidence in the effectiveness of government, as only a third of the respondents believed that "government would do something about a really serious health problem." Community $\mathrm{C}$ again had substantially different responses to these items as compared to the two other, lower-income areas. The wealthier respondents were far less likely to strongly agree that there were enough laws or that the government would act where there was a problem. Residents from Community B had a much higher level of confidence that the government would take care of a serious environmental problem.

\section{Risk beliefs}

While a majority of the respondents overall (58\%) agreed or strongly agreed that "most chemicals cause cancer," almost three-fourths agreed that the risk posed by smoking and diet was greater than the risk due to chemicals in the environment (Table 2). Over two-thirds of the sample felt that they could protect themselves from environmental pollutants by "improving their individual lifestyle, such as by exercising and eating properly." Residents from the higherincome area, Community C, were far less likely to believe that most chemicals caused cancer, and somewhat less likely to think that lifestyle factors posed greater risk than environmental contaminants. There was a clear difference in the belief that one could pro- tect oneself, with $82 \%$ of the residents from semirural Community A agreeing or strongly agreeing, as compared to only $54 \%$ of those from the highincome, suburban community.

Overall, the respondents appeared to be quite risk-adverse, with $63 \%$ strongly agreeing that they wouldn't drink tap water containing "even a tiny amount of a substance that could make me sick" (Table 2). Again there was a clear difference among the communities, with $82 \%$ of those from Community A strongly agreeing with the statement, as compared to only $31 \%$ in the most affluent neighborhood. While about a third (32\%) of the respondents strongly agreed that a "risk-free environment" was an attainable goal, a somewhat lower proportion (19\%) strongly felt that "El Pasoans should be willing to accept some risk to their health in order to improve the economy." There again was a strong distinction in these beliefs between the higher-income community (Community C) and the other areas, with only $2 \%$ of the residents from the higherincome community strongly agreeing with this statement.

Community $\mathrm{C}$ residents also differed in their level of concern about health risks and in their feelings of control (Table 2). While over $35 \%$ of the respondents from the two lower-income communities felt that El Paso was "too worried about small health risks," only $16 \%$ of the respondents from Community $\mathrm{C}$ agreed with this statement. Similarly, about half of the respondents from both Community A and Community B felt that they had "little control over risks to my health," while only a third of the residents from Community $\mathrm{C}$ shared this attitude. Just under half (47\%) of all respondents agreed that they "don't worry about chemicals because there are just too many other things in my life that I have to deal with."

\section{Addressing environmental problems}

Overall, the respondents seemed to believe strongly in the potential for solving environmental problems, but without necessarily having a clear di- rection on how to do so (Table 3). There was almost universal agreement that people working together could change the environment, that "changes people make today will have an effect on the environment of the future," and that there are things that people could do to improve the environment. At the same time, 50\% responded they were "completely at a loss about what to do about environmental risks," indicating a lack of knowledge about what actions individuals might take to improve the environment.

\section{DISCUSSION}

Differences in attitudes and beliefs about environmental risk were found among the three communities studied. Regarding regulations and experts, the residents of the suburban, higherincome community were more likely to believe that more laws regulating chemicals were needed, even though residents of the semirural community were more likely to perceive that they had been exposed to chemicals because of aerial application of pesticides on nearby fields. It may be that the more rural group sees laws regulating chemicals as a possible threat to their livelihood, since many are employed in agriculture. A much higher proportion of respondents from the two low-income areas agreed that some risks had to be accepted to strengthen the economy.

Seventy-five percent of the respondents felt that experts could make accurate estimates of risk. This did not differ by area of the county, and it points to a general lack of understanding about how experts determine risk. The belief that experts can accurately estimate risk may lead to many of the misunderstandings that are common in risk communication efforts. People may feel that the experts are just not telling everything they know, when, in fact, they may be sharing as much as they understand about the risk. Agencies should include information on how risk is determined when preparing risk communication materials. 
TABLE 2. Beliefs about environmental and health risks, El Paso County, Texas, 1995

\begin{tabular}{|c|c|c|c|c|c|}
\hline \multirow[b]{2}{*}{ Statement and responses } & & \multicolumn{3}{|c|}{ Communitya, b } & \multirow[b]{2}{*}{ Overall } \\
\hline & & A & B & $\mathrm{C}$ & \\
\hline "Most chemicals cause cancer."c & $\begin{array}{r}\text { SA } \\
A \\
D \\
\text { SD }\end{array}$ & $\begin{array}{r}63.4 \\
22.0 \\
9.8 \\
4.9\end{array}$ & $\begin{array}{l}45.7 \\
17.4 \\
26.1 \\
10.9\end{array}$ & $\begin{array}{r}6.7 \\
22.2 \\
53.3 \\
17.8\end{array}$ & $\begin{array}{l}37.9 \\
20.5 \\
30.3 \\
11.4\end{array}$ \\
\hline $\begin{array}{l}\text { "People can protect themselves against health risks from } \\
\text { pollution by improving their individual lifestyle, such as by } \\
\text { exercising and eating properly."c }\end{array}$ & $\begin{array}{r}\text { SA } \\
A \\
D \\
\text { SD }\end{array}$ & $\begin{array}{r}68.6 \\
13.7 \\
9.8 \\
7.8\end{array}$ & $\begin{array}{r}41.7 \\
35.4 \\
14.6 \\
8.3\end{array}$ & $\begin{array}{l}26.1 \\
28.3 \\
28.3 \\
17.4\end{array}$ & $\begin{array}{l}46.2 \\
25.5 \\
17.2 \\
11.0\end{array}$ \\
\hline $\begin{array}{l}\text { "I believe a risk-free environment is an attainable goal } \\
\text { in El Paso." }\end{array}$ & $\begin{array}{r}\text { SA } \\
A \\
D \\
\text { SD }\end{array}$ & $\begin{array}{l}48.0 \\
14.0 \\
14.0 \\
24.0\end{array}$ & $\begin{array}{r}44.0 \\
24.0 \\
24.0 \\
8.0\end{array}$ & $\begin{array}{r}2.2 \\
37.8 \\
26.7 \\
33.3\end{array}$ & $\begin{array}{l}32.4 \\
24.8 \\
21.4 \\
21.4\end{array}$ \\
\hline $\begin{array}{l}\text { "El Pasoans should be willing to accept some risk to their } \\
\text { health in order to strengthen the economy." }\end{array}$ & $\begin{array}{r}\text { SA } \\
A \\
D \\
S D\end{array}$ & $\begin{array}{l}29.4 \\
23.5 \\
15.7 \\
31.4\end{array}$ & $\begin{array}{l}22.9 \\
27.1 \\
16.7 \\
33.3\end{array}$ & $\begin{array}{r}2.2 \\
20.0 \\
33.3 \\
44.4\end{array}$ & $\begin{array}{l}18.8 \\
23.6 \\
21.5 \\
36.1\end{array}$ \\
\hline $\begin{array}{l}\text { "El Paso society is becoming too worried about small } \\
\text { health risks."c }\end{array}$ & $\begin{array}{r}\text { SA } \\
A \\
D \\
\text { SD }\end{array}$ & $\begin{array}{l}22.9 \\
14.6 \\
20.8 \\
41.7\end{array}$ & $\begin{array}{l}23.4 \\
25.5 \\
25.5 \\
25.5\end{array}$ & $\begin{array}{r}0.0 \\
16.3 \\
44.2 \\
39.5\end{array}$ & $\begin{array}{l}15.9 \\
18.8 \\
29.7 \\
35.5\end{array}$ \\
\hline "I feel I have very little control over risks to my health." & $\begin{array}{r}\text { SA } \\
A \\
D \\
\text { SD }\end{array}$ & $\begin{array}{l}27.5 \\
23.5 \\
27.5 \\
21.6\end{array}$ & $\begin{array}{l}28.0 \\
20.0 \\
32.0 \\
20.0\end{array}$ & $\begin{array}{r}8.7 \\
26.1 \\
45.7 \\
19.6\end{array}$ & $\begin{array}{l}21.8 \\
23.1 \\
34.7 \\
20.4\end{array}$ \\
\hline
\end{tabular}

Mistrust of agencies and government officials was evident in that the majority of the sample did not believe that decisions should be left to the experts. There were differences by community, however, with the two lowerincome communities more likely to agree that experts should make the decisions. About half of the respondents in all three communities appeared to have little trust in government actions when there was a problem.

In order to improve the environment and regain the trust of the public, agencies must change their approach to educating the public. First, they must act in ways that will earn trust. According to Chess and associates (17), agencies can take a number of steps to do this. These include involv- ing community residents in decisions that affect their lives, releasing information as soon as it is available, paying attention to people's feelings, following up with community members, admitting making mistakes, being honest about not knowing answers to specific questions, using plain rather than technical language, and making sure that all agencies-and everyone 
TABLE 3. Attitudes and beliefs about addressing environmental problems, El Paso County, Texas, 1995

\begin{tabular}{|c|c|c|c|c|c|}
\hline \multirow[b]{2}{*}{ Statement and responses } & & \multicolumn{3}{|c|}{ Community ${ }^{a, b}$} & \multirow[b]{2}{*}{ Overall } \\
\hline & & A & B & $\mathrm{C}$ & \\
\hline \multirow[t]{3}{*}{ "If people work together, they can change the environment." } & SA & 94.1 & 92.0 & 63.0 & 83.7 \\
\hline & D & 0.0 & 0.0 & 4.3 & 1.4 \\
\hline & SD & 2.0 & 2.0 & 0.0 & 1.4 \\
\hline \multirow{2}{*}{$\begin{array}{l}\text { "Changes that people make today will have an effect on the } \\
\text { environment of the future." }\end{array}$} & SA & 90.0 & 74.0 & 65.2 & 76.6 \\
\hline & SD & 2.0 & 4.0 & 2.2 & 2.7 \\
\hline \multirow{4}{*}{$\begin{array}{l}\text { "There are things I can do that will make a difference in } \\
\text { improving the environment." }\end{array}$} & SA & 86.0 & 75.0 & 52.2 & 71.5 \\
\hline & A & 10.0 & 16.7 & 39.1 & 21.5 \\
\hline & D & 2.0 & 4.2 & 8.7 & 4.9 \\
\hline & SD & 2.0 & 4.2 & 0.0 & 2.1 \\
\hline hazardous waste and air pollution." & SD & 58.8 & 59.2 & 76.1 & 64.4 \\
\hline \multirow{4}{*}{$\begin{array}{l}\text { "I feel completely at a loss about what to do about } \\
\text { environmental risks." }\end{array}$} & $S A$ & 48.0 & 28.0 & 8.7 & 28.8 \\
\hline & $A$ & 14.0 & 18.0 & 32.6 & 21.2 \\
\hline & $D$ & 24.0 & 32.0 & 28.3 & 28.1 \\
\hline & SD & 14.0 & 22.0 & 30.4 & 21.9 \\
\hline
\end{tabular}

within each agency-give the same information.

Residents of the higher-income suburban community in El Paso were more likely than persons in the two lower-income communities to accept a small risk, as evidenced by the response to the statement about tiny amounts of a substance in tap water. However, the better-off residents were less likely to feel that El Pasoans should accept some risk to strengthen the economy. Residents in the lowerincome areas of the city didn't want to take risks with tap water, but were more likely to be willing to accept some risk for the sake of the economy. Residents in the two lower-income areas were also more likely to agree that a risk-free environment is possible. Such a belief can wreak havoc on any risk communication campaign. If people believe that the world can be risk-free, they are not likely to attend to messages about the relative risks of different options.
Almost everyone agreed that communities and individuals could have a positive impact on the environment. However, $50 \%$ of the respondents said they had no idea what they as individuals could do to make a difference. In the El Paso area it appears that people need basic information about what they can do to improve the environment. In the area of risk and environmental education, there is still a need for basic information transfer.

Chess and colleagues $(18,19)$ found that agencies devote more effort to responding to requests for information than on starting a dialogue with communities or alerting communities to risk, and that the agencies rarely use surveys as a way to collect public input. Santos and associates (20) found similar results when they looked at industries submitting Toxic Release Inventory reports required under the United States Government's Superfund Amendment Reauthorization Act Title III (also known as the "Emergency Planning and Community Right-to-Know Act of 1986"). Those researchers found that fewer than $10 \%$ of the industries used surveys or focus groups to identify audiences and their concerns. Agencies should be more proactive in reaching out to communities. Surveys similar to the one used in this research might be a useful starting point for dialogue.

Health and environmental agencies are expected to communicate risks and the means of prevention to entire communities. Communities, however, are varied in their makeup. It is imperative that risk communicators understand the many different attitudes and beliefs of individuals within communities.

The communication of environmental risk is a tricky business. There are many complications when dealing with environmental issues, not the least of which is the tension that usually exists in the relationships among agencies, corporations, and communities. In many instances, communities feel powerless to make any changes or 
to have real input into decisions. The role of those communicating on environmental risk should be to help communities understand the nature of the risk, the uncertainty of risk assessment, and the options that community residents have available to protect themselves. Before an agency can de- velop meaningful interventions, the agency must access and come to understand the attitudes of the varied stakeholders in the community.

\section{REFERENCES}

1. Sandman P. Responding to community outrage: strategies for effective risk communication. Fairfax, Virginia: AIHA Press; 1993.

2. Sandman P. Hazard versus outrage in the public perception of risk. In: Covello V, McCallum D, Pavlova M, eds. Effective risk communication. New York: Plenum Press; 1989. p. 45-49.

3. Hance BJ, Chess C, Sandman PM. Setting a context for explaining risk. Risk Anal 1989; 9:113-117.

4. Sandman P. Explaining environmental risk. Washington, D.C.: United States, Environmental Protection Agency; 1986.

5. National Research Council. Improving risk communication. Washington, D.C.: National Academy Press; 1989.

6. Slovic P. Trust, emotion, sex, politics, and science: surveying the risk-assessment battlefield. In: Bazerman M, Messick D, Tenbrunsel A, Wade-Benzoni K, eds. Psychological perspectives to environment and ethics in management. San Francisco: JosseyBass; 1997.

7. Slovic P. Perception of risk. Science 1987;236: 280-285.

8. Cvetkovich G, Earle TC. Environmental hazards and the public. J Social Issues 1992;48(4): $1-20$
9. Ziemer PL. Radiation protection information: can you trust the government's risks or risk the government's trust? Health Phys 1999; 77(1):9-15.

10. Flynn J, Burns W, Mertz CK, Slovic P. Trust as a determinant of opposition to a high-level radioactive waste repository: analysis of a structural model. Risk Anal 1992;12:417-430.

11. Slovic P, Layman M, Kraus N, Flynn J, Chalmers J, Gesell G. Perceived risk, stigma, and potential economic impacts of a highlevel nuclear waste repository in Nevada. Risk Anal 1991:11(4):683-696.

12. Slovic P. Perceived risk, trust and democracy. Risk Anal 1993;13(6):675-682.

13. University of Texas System. Texas-Mexico border county demographics and health statistics: 1994. Edinburg, Texas: University of Texas System, Texas-Mexico Border Health Coordination Office; 1994

14. United States, Environmental Protection Agency. US-Mexico Border XXI Program framework document. Washington, D.C.: EPA; 1996. (EPA Publication No. 160-R-96003).

15. Slovic P, Flynn J, Mertz CK, Mullican L. Health-risk perception in Canada. Ottawa: Department of National Health and Welfare; 1993. (Report No. 93-EHD-170).
16. Byrd TL, VanDerslice J, Peterson SK. Variation in environmental risk perceptions and information sources among three communities in El Paso, Texas. Risk: Health, Safety and Environment 1997;8(4):355-372.

17. Chess C, Hance BJ, Sandman PM. Improving dialogue with communities: a short guide to government risk communication. Trenton, New Jersey, United States of America: New Jersey Department of Environmental Protection; 1988.

18. Chess C, Salomone KL, Sandman PM. Risk communication activities of state health agencies. Am J Public Health 1991; 81(4):489-491.

19. Chess C, Salomone KL. Rhetoric and reality: risk communication in government agencies. J Environ Educ 1992; 23(3):28-33.

20. Santos SL, Covello VT, McCallum DB. Industry response to SARA Title III: pollution prevention, risk reduction, and risk communication. Risk Anal 1996;16(1):57-66.

Manuscript received on 13 July 2000. Revised version accepted for publication on 8 December 2000
RESUMEN

\section{Actitudes y creencias sobre los agentes nocivos ambientales en tres comunidades diferentes de la frontera de Texas con México}

Objetivo. Una vez que la comunicación de información sobre los riesgos relacionados con agentes nocivos ambientales no ha sido fácil para los organismos gubernamentales y las industrias, el objetivo de este estudio consistió en comprender mejor las actitudes y creencias de tres comunidades, con el fin de ayudar a estos organismos a desarrollar mejores campañas de información sobre los riesgos.

Métodos. En este estudio se examinaron las actitudes y creencias sobre los riesgos ambientales en tres comunidades diferentes de la frontera entre Texas y México, en el condado de El Paso. Durante el verano de 1995 se realizó una encuesta a domicilio en la que se entrevistaron 147 individuos con un cuestionario basado en un instrumento preexistente. Las entrevistas se realizaron en tres zonas diferentes del condado: una semirrural y otra urbana de bajos ingresos y una suburbana de mayores ingresos. Los sectores específicos de cada una de las tres comunidades incluidos en la muestra fueron seleccionados aleatoriamente. Se evaluaron las actitudes y creencias sobre las leyes y los expertos, los agentes nocivos y los riesgos, y la forma de abordar los problemas ambientales. Resultados. Las actitudes y creencias variaron según la comunidad, especialmente con respecto a la evaluación de los riesgos de varios agentes nocivos. En general hubo desconfianza en los organismos gubernamentales y las industrias, una fuerte creencia de que es posible mejorar el ambiente, y desconocimiento de las acciones que los individuos pueden poner en marcha para mejorarlo.

Conclusiones. Los organismos gubernamentales necesitan encontrar formas de incrementar su credibilidad pública y deberían sondear las comunidades con el fin de comprender las actitudes de los residentes. 